\title{
Correction to: The low-copy nuclear gene Agt 1 as a novel DNA barcoding marker for Bromeliaceae
}

\author{
Fabian Bratzel ${ }^{1,2^{*}}$, Sascha Heller ${ }^{3}$, Nadine Cyrannek ${ }^{3}$, Juraj Paule ${ }^{1}$, Elton M. C. Leme ${ }^{4}$, Anna Loreth², \\ Annika Nowotny ${ }^{2}$, Markus Kiefer ${ }^{2}$, Walter Till ${ }^{5}$, Michael H. J. Barfuss ${ }^{5}$, Christian Lexer $^{5}$, Marcus A. Koch ${ }^{2}$ and \\ Georg Zizka $a^{1,3}$
}

\section{Correction to: BMC Plant Biol 20, 111 (2020) \\ https://doi.org/10.1186/s12870-020-2326-5}

In the original publication [1] an incorrect version of Additional file 1 was used during typesetting. The incorrect and correct versions of Additional file 1 are available in this correction article. The original article has been updated. The publisher apologizes to the authors and readers for the inconvenience.

\section{Supplementary Information}

The online version contains supplementary material available at https:/doi. org/10.1186/s12870-020-02743-3.

Additional file 1: Incorrect version of Additional file 1.

Additional file 2: Correct version of Additional file 1.

\section{Author details}

${ }^{1}$ Department of Botany and Molecular Evolution, Senckenberg Research Institute and Natural History Museum Frankfurt, Senckenberganlage 25, 60325 Frankfurt am Main, Germany. ${ }^{2}$ Centre for Organismal Studies (COS) Heidelberg, Department for Biodiversity and Plant Systematics, University of Heidelberg, Im Neuenheimer Feld 345, 69120 Heidelberg, Germany. ${ }^{3}$ Institute for Ecology, Evolution and Diversity, Goethe University, Max-von-Laue-Straße 13, 60438 Frankfurt am Main, Germany. ${ }^{4}$ Marie Selby Botanical Gardens, 811 South Palm Avenue, Sarasota, FL 34236, USA. ${ }^{5}$ Department of Botany and

The original article can be found online at https://doi.org/10.1186/s12870020-2326-5.

* Correspondence: fabian.bratzel@senckenberg.de

'Department of Botany and Molecular Evolution, Senckenberg Research Institute and Natural History Museum Frankfurt, Senckenberganlage 25, 60325 Frankfurt am Main, Germany

${ }^{2}$ Centre for Organismal Studies (COS) Heidelberg, Department for Biodiversity and Plant Systematics, University of Heidelberg, Im Neuenheimer Feld 345, 69120 Heidelberg, Germany

Full list of author information is available at the end of the article
Biodiversity Research, Faculty of Life Sciences, University of Vienna, Rennweg 14, 1030 Vienna, Austria.

Published online: 30 December 2020

Reference

1. Bratzel F, Heller S, Cyrannek N, et al. The low-copy nuclear gene Agt1 as a novel DNA barcoding marker for Bromeliaceae. BMC Plant Biol. 2020;20:111. https://doi.org/10.1186/s12870-020-2326-5.

(C) The Author(s). 2020 Open Access This article is licensed under a Creative Commons Attribution 4.0 International License, which permits use, sharing, adaptation, distribution and reproduction in any medium or format, as long as you give appropriate credit to the original author(s) and the source, provide a link to the Creative Commons licence, and indicate if changes were made. The images or other third party material in this article are included in the article's Creative Commons licence, unless indicated otherwise in a credit line to the material. If material is not included in the article's Creative Commons licence and your intended use is not permitted by statutory regulation or exceeds the permitted use, you will need to obtain permission directly from the copyright holder. To view a copy of this licence, visit http://creativecommons.org/licenses/by/4.0/ The Creative Commons Public Domain Dedication waiver (http://creativecommons.org/publicdomain/zero/1.0/) applies to the data made available in this article, unless otherwise stated in a credit line to the data. 